\title{
Genetic Variability and Association Among Bulb Yield and Yield Related Traits of Garlic (Allium sativum L.) Genotypes at Bishoftu Agricultural Research Center, Ethiopia
}

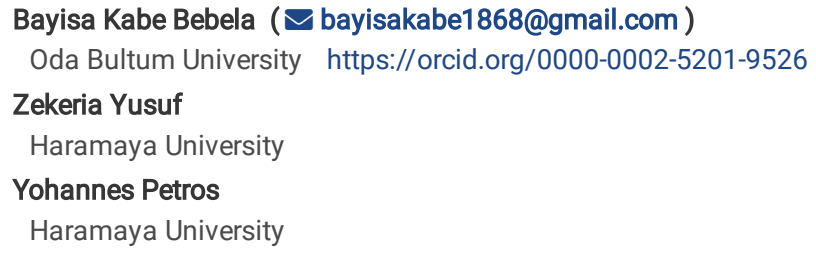

\section{Research Article}

Keywords: Clustering, Correlation, Genetic variability, Genotypes, Heritability

Posted Date: November 4th, 2021

DOI: https://doi.org/10.21203/rs.3.rs-1023092/v1

License: @ (i) This work is licensed under a Creative Commons Attribution 4.0 International License. Read Full License 


\section{Abstract}

Garlic (Allium sativum L.) is the second most important Allium species next to onion (Allium cepa L. in the world and from Africa, Ethiopia is ranked second most garlic produce next to Egypt. It is one of the most important vegetable crops in Ethiopia and is used as a component of food, cash and has also a tremendous use in the formulation of local medicines. Among abiotic factors affecting garlic production and productivity using garlic genotype which is susceptible for different biotic and abiotic agents contributed huge yield loss in agriculture center. Therefore, this field experiment was conducted to assess the genetic variability in garlic genotypes, to determine association among traits and estimate the direct and indirect effects of traits on bulb yield. The field evaluation of 34 genotypes and 2 released varieties (G-HL and Chefe) was conducted in 6x6 Triple Lattice Design at Bishoftu Agricultural Research Center during January 2020 to May 2020. Results of analysis of variance revealed the presence of significant differences among genotypes for 18 traits. The variation observed among genotypes for bulb yield ranged from 43.80 to $147.20 \mathrm{~kg}$ ha- 1 . The six genotypes had mean performances higher than the highest performing check variety (G-HL=99.5Kg ha-1). Generally, the results of this study showed the presence of variations among genotypes for agro-morphology traits with a wide range of genetic distances that could allow selection and/or hybridization of genotypes after the results of this study are confirmed across locations and over the years.

\section{Introduction}

Garlic is a diploid species $(2 n=2 x=16)$ is a widely cultivated in Ethiopia and preferred by most It is the most vital crop of the genus Allium next onion (Allium cepa L.) (Benke et al., 2020a and Khandagale et al., 2020) and supposed to have risen in Central Asia in India has with over 5000 years cultivation past (Benke et al., 2020a). The average annual world production of garlic is about $24,836,920$ tons on $1,465,772$ ha of land with the productivity of 16.9 t/ha (FAO, 2012 ). Its average yield has increased from 3.48 to 5.27 MT per ha over the previous 40 years in India (FAOSTAT, 2018). Garlic, on the other hand, has an inferior efficiency in genetic development than onion, owed to sexual sterility, as a importance, do not produce seeds, therefore cloves are used to asexually propagation (Manjunathagowda et al., 2017).

In Ethiopia, garlic grows probably throughout the cooler part of the country in the altitude ranging from 1800-2800m (Edwards et al., 1997). It is cultivated in home gardens and in small irrigated fields by smallholder farmers and cooperatives. It is the second most important Allium species next to onion (Allium cepa L.) in the world and from Africa, Ethiopia is ranked second most garlic produce next to Egypt (FAOSTAT, 2018). It is one of the most important vegetable crops in Ethiopia and is used as a component of food, cash and has also a tremendous use in the formulation of local medicines and especially the importance of this spice is increasing owing to its wide range of medicinal properties (Chanchan et al., 2014).

However is importance in Ethiopia, its production and productivity was (9.18 t ha-1) which is lower than the world's average production (CSA, 2018). This is due to biotic and abiotic factors. Among abiotic factors affecting garlic production and productivity using garlic genotype which is susceptible for different biotic and abiotic agents contributed huge yield loss in agriculture center. The knowledge of the nature of the association of bulb yield with yield characters is necessary for yield improvement through selection of better varieties (Haydar et al., 2007). The genetic variability on yield and yield contributing characters of the crop species need to be properly assessed for its improvement (Alam et al., 2010). Production and productivity do not depend only on area and cultural practices but also on the genotypes of the crop and environmental conditions (Lawande et al., 2009).

The information of genetic variability and association between garlic yield and its components would improve the plant breeding programs by identifying appropriate indices for selecting garlic varieties (Singh et al., 2011). In many situations, formal seed supply has been unable to meet the framers' needs, due to its limited supply capacity, a focus confined to only a few crops, or because it supplies inappropriate varieties. This, along with concerns for farmer participation and local knowledge, partly explains the growing interest in supporting small-scale farmers' seed production. Production and productivity do not depend only on area and cultural practices but also on the genotypes of the crop and environmental conditions (Lawande et al., 2009).

The major reason for low yield is the lack of improved high yielding varieties of garlic that are adapted to local conditions (Wen et al., 2020). Despite the importance of the crop, so far very limited breeding work has been done. The abundance of germplasm collection is determined by the amount of genetic variability present in the germplasm. Most crops breeding programme aimed at increasing the plant productivity requires consideration not only of yield, but also its components that have direct or indirect influences on crop yield. Therefore, this study was designed to evaluate the genetic variability, heritability, genetic advance and associations among characters of garlic genotypes and to estimate the contribution of each trait to yield improvement in garlic.

\section{Materials And Methods Description of the Research Site}

The experiment was conducted at Bishoftu Agricultural Research Center (BARC) in the central highlands of Ethiopia, which is located 45km southeast from Addis Ababa with the geographical locations of $8^{\circ} 45^{\prime} \mathrm{N}$ Latitude, $35^{\circ} 9^{\prime} \mathrm{E}$ Longitude and at an elevation of $1900 \mathrm{~m}$.a.s.I. The average annual rainfall is $686.9 \mathrm{~mm}$ with average minimum and maximum temperature ranging from $10.9^{\circ} \mathrm{C}$ to $27.0^{\circ} \mathrm{C}$ with a mean value of $18.9^{\circ} \mathrm{C}$ respectively. The soil of the experimental site is black soil (vertisol or vertosol) $86 \%$. The study was conducted in the off-season during January 2020 to May 2020 at the research sites.

\section{Experimental Materials}

Thirty-six garlic accessions that include two standard checks which were obtained from the Bishoftu Agricultural Research Center were used for the study, including Agrifound Parvati as a check. The germplasms were collected from different major garlic producing parts of the Region, Zone and District (Table 1). 


\section{Experimental Layout}

The experimental material was laid out in a $6 \times 6$ Triple Lattice Design (TLD) with three replications. Cloves were planted in the field in January, 2020 . The plot size was $2 \mathrm{~m}$ length and $1.5 \mathrm{~m}$ width, consisting 4 rows with 5 plants per row, which comprised a total of 20 plants per plot; the clove was planted in a space of $30 \mathrm{~cm} \times 50 \mathrm{~cm}$ between rows and plants, respectively. The spacing between plots, blocks and replications was $0.5 \mathrm{~m}, 1 \mathrm{~m}$ and $1.5 \mathrm{~m}$ respectively. The standard cultural practices recommended in the "Package of Practices for Vegetable Crops" was followed for raising a healthy crop of garlic (Anonymous, 2009) and Agronomic practices recommended by Getachew et al., (2009) was followed to manage the plants.

\section{Data Collection}

All agronomic, bulb yield and yield related data were recorded from six randomly sampled plants in the middle four rows of each experimental unit/plot. However; phonological parameter was taken on plot basis. The collected quantitative traits were days to emergence (DE), Days to maturity (DM), Plant height $(\mathrm{PH})$, Leaves Length (LL), Leaves Width (LW), Number of leaves per plant (NLPP), Neck diameter (ND), Bulb length (BL), Bulb diameter (BD), Bulb weight (BW), Clove length (CL), Clove diameter (CD), Clove weight (CW), Number of cloves per bulb (NCPB), Bulb yield per plot (BYPL), Biological yield per plant (BYPT), Bulb yield per hectare (BYPH) $\mathrm{Kg} / \mathrm{ha}^{-1}$ and Harvest Index (HI \%).

\section{Statistical Analysis}

Data collected for quantitative characters were subjected to analysis of variance (ANOVA) for triple lattice design (Table 2) using proc lattice and proc GLM procedures of SAS version 9.2 (SAS Institute Inc, 2008). The difference between treatment means were compared using TLD at $5 \%$ and $1 \%(P<0.05)$ and $(P<0.01)$ probability levels, respectively. The genetic parameters, including the Genotypic and Phenotypic variance, Genotypic and Phenotypic coefficient of variance, Heritability (Broad Sense) and the expected Genetic advance (GA), Genetic advances as a percent of the mean (GAM) were calculated using the formula given by Falconer, (1981) and Johnson et al., (1955).

The following models were used in the following analysis of variance:

$$
\boldsymbol{Y}_{i j k}=\mu+\boldsymbol{g}_{i}+\boldsymbol{r}_{j}+\boldsymbol{b}_{k j}+\varepsilon_{i j k}
$$

Where: $Y_{i j k}=$ the response of $Y$ trait from the $i^{\text {th }}$ genotype, grown in the $k^{\text {th }}$ incomplete block of $j^{\text {th }}$ replicate

$$
\begin{array}{ll}
\mu=\text { grand mean } & \mathrm{b}_{\mathrm{kj}}=\text { the effect of } k^{\text {th }} \text { incomplete block in a } j^{\text {th }} \text { replicate } \\
\mathrm{g}_{\mathrm{i}}=\text { the effect of the } i^{\text {th }} \text { genotype } & \varepsilon_{\mathrm{ijk}}=\text { experimental error/error variance } \\
\mathrm{r}_{\mathrm{j}}=\text { the effect of the } j^{\text {th }} \text { replicate } &
\end{array}
$$

\section{Results}

\section{Analysis of Variance (ANOVA)}

The analysis of variance for the 18 characters studied is given in (Table 3). Analysis of Variance (ANOVA) was carried out for the characters as per the procedure outlined by Gomez (1984). The mean squares due to accessions were significant $(P<0.05)$ and highly significant $(p<0.01)$ for all traits. There was a highly significant difference $(\mathrm{P}<0.01)$ among the tested garlic genotypes for days to emergence, days to maturity, plant height, leaves number per plant, neck diameter, bulb length, bulb diameter, bulb weight, clove length and number of cloves per bulb, bulb yield per plot, biological yield per plant and bulb yield per hectare which is due to genotype. Significant difference $(P<0.05)$ was observed for leaves width and which due to genotype except for leaves length, clove diameter, clove weight and harvest index which showed non-significant genotype effects.

Awel et al., (2011) reported the existence of genetic diversity within shallot produced in Ethiopia which is in related with present findings. In addition, Abebech et al., (2021) found variability in garlic for tested characters which supports the present result.

\section{Mean Performance of Genotypes Phenology and Growth Character}

The results of mean performances, minimum, maximum values and CV and LSD for the 18 quantitative traits of the garlic accessions are summarized in Appendix Table 1. Similar results were also obtained by of Abdlkafer-Halmy et al., (2011), that significant variations exist within and among families of garlic for bulb and clove weight, number of cloves per bulb, flower stack height. Leaves length revealed non-significant variation among the genotypes. The results are in related with the findings of (Abebech et al., 2021) (Table 3). It is indicated from (Appendix Table 1) that the leaves length different from each other among the maximum mean performance of leaves length was recorded in G-092-3/95(29.56 cm) and minimum mean performance of leaves length (18.09cm) was recorded in G-119/06. The results are in agreement with the findings of Ahmed et al., (2018). Leaves width showed a wide range of variation from $0.62 \mathrm{~cm}$ for G-119/06 to $1.95 \mathrm{~cm}$ for G-013/04 (Appendix Table 1). Maximum mean performance of leaves width was recorded in G-013/04(1.95cm. 
Minimum mean performance of leaves width was recorded in G-119/06 $(0.62 \mathrm{~cm})$. The examination of data indicated that the mean value leaves width was $(1.30 \mathrm{~cm})$. Leaves width revealed significant variation among the genotypes (Table 3). The results are in agreement with the findings of Ahmed et al., (2018) and Guaray et al., (2018). The results are in related with the findings of Bhat et al., (2017) who reported that the mean performance of number of leaves per plant were $6.16,7.13,7.20,7.52$ and 7.75 , respectively in garlic. Neck diameter revealed significant variation among the genotypes (Table 3 ). The findings of Guaray et al., (2018) and Singh et al., (2015) are in close harmony with the results of the present study.

\section{Yield and Yield Components}

Bulb length revealed highly significant variation among the genotypes (Table 3). These findings are in accordance with the work of Abebech et al., (2021), Panse et al., (2013) and Vatsyayan et al., (2013) who reported significant variation among the genotypes for this character in garlic. Highly significant variation was recorded for bulb diameter in the genotypes (Table 3). These findings are similar to the work of Ahmed et al., (2018). The bulb weight exhibited highly significant variation among the genotypes (Table 3).

The analysis of variance indicated highly significant variation among genotypes for the clove length (Table 3 ). The results are in close conformity with Singh et al., (2015) and Kumar et al., (2017). Non-significant differences were observed among the genotypes for clove diameter (Table 3 ) and it ranged mean performance from $0.99 \mathrm{~cm}$ to $1.92 \mathrm{~cm}$ (Appendix Table 1). The findings of Kumar et al., (2017) are in close conformity with the results of the present study. Non-significant differences were observed among the genotypes for clove weight (Table 3).

Genotypes with late maturity, tall growing, large bulb length and bulb diameter produced more yield has been reported, Gaury et al., (2018) and Vatsyayan et al., (2013) reported wider range of variation in garlic germplasm for yield per plot. Highly significant variation among the genotypes for biological yield per plant was recorded (Table 3). Significant variation among the genotypes in bulb yield per hectare was recorded (Table 3). The results are in close conformity with findings for the character has been reported, Pervin et al., (2014) and Khar et al., (2015). Non-significant variation among the genotypes in the harvest index was recorded (Table 3).

\section{Estimates of Genetic Parameter \\ Estimates of genotypic and phenotypic coefficient of variation}

A large amount of variability was noticed with respect to all the characters under study. Phenotypic variability is the total variability, which is observable and consists of both genotype and environmental variation. Such variation is measured in terms of phenotypic variation and Sable et al., 2020 and Singh, 2015). In the present study, the phenotypic and genotypic variances were maximum for bulb yield per hectare (721.78) and (659.66) and minimum for neck diameter (0.054) and (0.030) (Table 5), respectively.

The results revealed a wide range of variability among 36 garlic genotypes for quantitative traits (Table 5). The highest phenotypic coefficients of variability were recorded for bulb yield per plot (37.83\%), clove diameter (34.57\%), bulb weight (34.29\%), number of cloves per bulb (30.49\%), bulb yield per hectare (30.22\%), neck diameter (29.05\%), biological per plant (26.25\%), leaves width (24.33\%), leaves length (22.97\%) and clove length (21.37\%). On the other hand, relatively moderate values were observed for clove weight (16.14\%), bulb length (14.52\%), plant height (13.45\%), bulb diameter (12.86\%) and number of leaves per plant (12.04\%). Low phenotypic coefficients of variation were observed for days to emergence (9.80\%), harvest index (8.32\%) and days to maturity $(4.22 \%)$. The estimates of the phenotypic coefficient of variability were slightly higher than its corresponding genotypic coefficient of variability for all traits. The highest estimates of the genotypic coefficient of variability were observed for, clove diameter (32.54\%), bulb yield per hectare (28.89\%), bulb yield per plot (23.93\%), number of cloves per bulb (22.89\%), bulb weight (22.76\%), biological per plant (25.06\%), leaves width (22.82\%), neck diameter (21.65\%) and clove length (20.18\%). On the other hand, relatively moderate values were observed for leaves length (19.53\%), clove weight (13.44\%), number of leaves per plant (11.41\%) and bulb length (10.54\%).

Low genotypic coefficients of variation were observed for plant height (9.77\%), bulb diameter (8.57\%), days to emergence (6.60\%), days to maturity (2.70\%) and harvest index (2.62\%). Therefore, the larger proportion of phenotypic variance observed on these traits was contributed from the genotypic variance than the environment variance and hence, it can be exploited in breeding programs. For those traits for which the genetic variance is large relative to the environmental variance, accessions may be evaluated adequately by testing in few replicates, location and years (Yebirzaf et al., 2017). High phenotypic variations were high genetic variability for different traits and less influence of the environment. Therefore, selection on the basis of phenotype can be effective for the improvement of these traits. Kassahun, (2006) reported high GCV and PCV estimates for bulb weight and bulb yield of garlic. Awel et al., (2011) also reported related results in that the phenotypic coefficient of variation (PCV) was higher than genotypic coefficient of variation (GCV).

\section{Heritability estimates in broad sense}

The heritability values for the 18 characters ranged from 9.89\% for harvest index to $91.39 \%$ for bulb yield per hectare related with (Abebech et al., 2021) (Table 4). A broad-sense heritability assessment provides information on the relative amount of genetic and environmental variation in the population. As reported by Wright (1921), genetic advance values are helpful in predicting the expected progress to be achieved through the process of selection. For categorizing the magnitude of heritability, Johnson et al., (1955) suggested the following limits: Heritability $(H)>60 \%$ - High $30-60 \%$ - Moderate and $<30 \%$ - Low.

Estimates of heritability and genetic advance in combination are more important for selection than heritability alone. Then the present study suggested that selection based on the most heritable traits such as biological yield per plant, number of leaves per plant, bulb length, bulb diameter, days to emergence, bulb yield per hectare, clove diameter, clove length, clove weight, number of cloves per bulb, neck diameter, plant height, leaves length, days to maturity, bulb yield per plant, leaves width and bulb weight would be effective for the development of garlic through breeding. This finding agreed with the findings of the report by (Divya et al., 2021). There would be a close correspondence between the genotypes and phenotypes due to the relatively small contribution of the environmental effect on the phenotypes. This finding agreed with the findings of the previous report by (Divya et al., 2021).

Page $4 / 16$ 
High heritability of different traits indicated that a large proportion of the phenotypic variance has been attributed to genotypic variance and reliable selection could be made for these traits on the basis of phenotypic expression (Maurya et al., 2015). The results do agree with (Divya et al., 2021), Yadav et al., (2003). High heritability values were observed for bulb yield per hectare (91.39\%) coupled with high PCV (30.22\%) and GCV (28.89\%), biological yield per plant (91.09\%) coupled with high PCV (26.25\%) and GCV (25.06\%), also high heritability (88.61\%) coupled with high PCV (34.57\%) and GCV(32.54\%), high heritability (85.18\%) coupled with high PCV (24.33\%) and GCV (22.82\%) and high heritability (89.10\%) coupled with high PCV (21.37\%) and GCV (20.18\%) and high heritability were observed for leaves width, clove diameter and clove length, respectively. This result is in agreement with Alemayehu et al., (2014).

Estimate of Expected Genetic Advance (GA) - High heritability suggested the major role of genetic constitution in the expression of characters and such performance of characters is considered to be repeatable A high value was recorded for bulb yield per hectare (50.58). Moderate values were obtained for biological yield per plant (16.46) and the remaining is produced the lowest. The moderate genetic advance as a percent of mean was obtained for bulb length (15.75\%), plant height (14.60\%) and bulb diameter (11.77\%). The lowest values were recorded for days to emergence (9.10\%), days to maturity (3.60\%) and harvest index (1.70\%). Gupta et al., (2007) observed high heritability coupled with high genetic gain for clove diameter (63.11\%) and neck diameter (60.00\%).

The findings of the present study are in relative with that of Abebech et al., (2021) and Meena et al., (2020) found higher values of heritability coupled with high genetic gain for bulb weight, cloves per bulb and bulb yield per plot. High heritability and high genetic gain for number leaf per plant and neck thickness. High heritability and high genetic gain for bulb yield per plot relative with that of was reported by Pervin et al., (2014). Abebech et al., (2021) and Meena et al., (2020) as mentioned that where the high heritability value is accompanied by high genetic advance. In the present study, the highest estimates of heritability were observed in the case of plant height and the highest genetic advance showed in bulb yield plot. High heritability coupled with high genetic advance in per cent of the mean was recorded for number of cloves per bulb, bulb yield per plot and weight of clove, width of the leaves and length of clove. This indicates that these traits were less influenced by the environment.

\section{Phenotypic and Genotypic Correlation Coefficient}

Results in Table 5 showed that bulb yield per plot had positive and highly significant genotypic and phenotypic correlations with plant height, leaves width, leaves number per plant, bulb length, bulb diameter, bulb weight, clove length, clove weight, number of cloves per bulb and biological yield per plant and showed positive significant with harvest index at phenotypic. Biological yield per plant showed positive and highly significant phenotypic correlation with all characters except with days to emergence, days to maturity, leaves length, harvest index and clove diameter (Table 5).

It showed positive and highly significant genotypic correlation with plant height, leaves width, leaves number per plant, neck diameter, bulb length, bulb diameter, bulb weight, clove length, clove weight, number of cloves per bulb and bulb yield per plot and showed negative and highly significant phenotypic correlation with bulb yield per hectare and showed positive and significant with clove diameter at phenotypic. Similar results have been reported by other researchers (Abebech et al., 2021).

\section{Path Coefficient Analysis}

Path coefficient analysis measures the direct and indirect contribution of independent variables on dependent variables and thus helps breeders in determining the yield components and understanding the cause of association between two variables (Baranwal et al., 2012). In this study, bulb yield was selected as a dependent variable and the others that had significant correlation of eighteen characters were selected as causal variables. The results of path analysis for direct and indirect effects of the characters studied both at genotypic and phenotypic level are illustrated in (Table 7 and 8 ) (Valter et al., 2019).

\section{Phenotypic direct and indirect effects of traits on bulb yield per plot}

Phenotypic path coefficient analysis showed that biological yield per plant followed by bulb weight, harvest index and leaves width exerted positive direct effect on bulb yield and bulb weight and leaves width had positive highly significant phenotypic correlation, except harvest index had positive significant phenotypic correlation (Table 6). Likewise, clove weight, neck diameter, days to emergence, bulb length and number of per plant exerted positive and small magnitude of direct effect but with positive and highly significant phenotypic association with bulb yield, except days to emergence showed positive significant phenotypic correlation. The residual effect in the present study was $(0.0172)$ (Table 6$)$, showing that $98.28 \%$ of the variability in bulb yield was explained by the component factors. The remaining $1.72 \%$ is explained by other traits not considered in the study. This further clarified that yield attributing traits chosen for the study of the garlic genotypes were good.

\section{Genotypic direct and indirect effects of traits on bulb yield per plot}

Biological yield had a high positive direct effect (0.998) on bulb yield per plot followed by leaves width, bulb length, clove length, clove weight and number of leaves per plant (Table 7). Biological yield showed had negative indirect via plant height, neck diameter, bulb diameter, bulb weight and number of cloves per bulb, while positive indirect effect via leaves width, number of leaves per plant, bulb length, clove length, clove weight. Besides its positive and highly significant correlation with bulb yield, leaves width showed direct positive low effect $(0.13)$ on bulb yield per plot. The agreements with the result were reported by Abebech et al., (2021) and Valter et al., (2019).

The residual effect was 0.0184 (Table 7), indicating that all the traits included in the study explained a high percentage of the variation in bulb yield ( $98.16 \%$ ), while other factors not included in the study can explain $1.84 \%$. So, the yield components used were good. It is also suggested that further study should be made with more characters to find out other traits which contribute the rest of the percentage of the yield. The residual effect (0.0184) indicated that most of the variability in bulb yield for the genotypes under the present has been explained by the independent variables included in the analysis.

\section{Principal Component Analysis}

The principal component analysis displayed that the gross variability experimental among the 36 test genotypes can be clarified with four principal components with eigenvalues greater than unity (Table 8). The first four components together accounted for about $79.67 \%$ of the total variation among the

Page 5/16 
genotypes with respect to all the 18 traits evaluated and displayed the presence of substantial genetic diversity among the genotypes for most of the characters below consideration. Individually, PC1, PC2, PC3 and PC4 in that order accounted for about $56.25 \%, 10.70 \%, 7.14 \%$ and $5.59 \%$ of the gross variation among the 36 garlic genotypes evaluated for 18 traits. Therefore, PCA also helps breeders for genetic development of traits such as yield that have little heritability specifically in primary generations via indirect selection for traits effective on yield (Rakesh et al ., 2018 and Golparvar et al., 2006).

\section{Genetic Divergence Analysis Clustering of genotypes}

The Euclidean distance matrix of garlic genotypes estimated from 18 quantitative traits was used to create dendrograms based on the Unweighted Pair-group methods with Arithmetic Means. Accordingly, the 36 garlic genotypes were grouped into three distinct clusters (Figure 1 and Table 9). Cluster II was the largest and consisted of nineteen genotypes (52.80\%) of the total genotypes. Cluster I and III consisted of twelve (33.33\%) and five (13.89\%) genotypes. This is because the cluster analysis sequestrates genotypes into clusters which exhibit high homogeneity within a cluster and high heterogeneity between clusters (Chatoo et al., 2018 and Jaynes et al., 2003).

\section{Cluster mean analysis}

The mean values of three clusters for 18 quantitative characters are presented in (Table 10). Cluster I had mean values greater than overall mean values of genotypes for plant height, leaves length, leaves width, number of leaves per plant, neck diameter, bulb length, bulb diameter, bulb weight, clove length, clove diameter, clove weight, number of cloves per bulb, bulb yield per plot, biological yield per plant, bulb yield per hectare and harvest index (\%). In addition, Cluster I had mean values lower than overall mean values of genotypes for days to emergence and days to maturity. Also, Cluster II had mean values equal with overall mean values of genotypes for neck diameter. Related with the results were reported by (Ranjitha et al., 2018). In addition, Cluster I and Cluster II had mean values greater than overall mean values of genotypes for plant height, leaves length, leaves width, number of leaves per plant, bulb diameter and harvest index while Cluster III had mean values greater than overall mean values of genotypes for days to emergence and days to maturity. This cluster had mean values lower than overall mean values of genotypes for the remaining traits. These two clusters (I and II) consisted of 31 (86.11\%) with higher bulb yield and mean values greater than overall mean values of genotypes for most desirable traits suggested that selection of genotypes and/or further evaluation of members of these clusters is possible to develop varieties for the study area (Ranjitha et al., 2018).

The two clusters (I and II) consisted of thirty-one genotypes with a high mean bulb yield, but the members of these clusters were late maturing than the average yield maturity of genotypes. Cluster III consisted of five genotypes had lower plant height, leaves length, leaves width, number of leaves per plant, neck diameter, bulb length, bulb diameter, bulb weight, clove length, clove diameter, clove weight, number of clove per bulb, bulb yield per plot, biological yield per plant, bulb yield per hectare, harvest index (\%) but with higher mean values for days to emergence, days to maturity. This result is in related with Rakesh et al .,( 2018) and Panthee et al., (2006) that had found three major clusters in garlic using morphological traits.

\section{Discussion}

The highly significant differences indicate the existence of large variability among genotypes. There were less coefficients of variation in most of the characters indicating good precision of the experiment. These results indicate the presence of variability among the genotypes used for effective selection or vegetable improvement. Similar results were also obtained by Abdlkafer-Halmy et al., (2011), mentioned that significant variations exist within and among families of garlic for bulb and clove weight, number of cloves per bulb, owner stalk height, number of cloves per bulb, plant height and days to maturity. The analysis of variance indicated highly significant differences among the genotypes for days to emergence and days to maturity (Table 3 ). Variation in maturity has been reported by Panse et al., (2013).

The analysis of variance indicated significant variation among the genotypes for plant height with values ranging from 25.61 to $41.61 \mathrm{~cm}$ (Table 3 ) and (Appendix Table 1), respectively. Variability in plant height was due to the inherent genetic makeup of the different genotypes. The variation in the number of leaves per plant in the genotypes was due to different genetic building of the genotypes. Enhanced number of leaves may be due to activated physiological processes by stimulating factors in the metabolism and growth of the plant. The number of leaves per plant revealed highly significant variation among the genotypes (Table 3). Number of leaves resulted in more production of chlorophyll that ultimately led to more photosynthesis and hence high bulb weight (Yadav et al., 2012). Present results were confirmed by findings Gupta et al., (2007), Osman and Moustafa, (2009 and Singh et al., (2015) who also reported that different garlic genotypes differed significantly for average bulb weight.

The variability in clove weight in garlic has been reported by Gaury et al., (2018). Highly significant differences among the genotypes were observed for this character (Table 3). A significant amount of variability for number of cloves per bulb was reported by Singh et al., (2015) and Kumar et al., (2017). The analysis of variance indicated highly significant differences among the genotypes for bulb yield per plot (Table 3$)$. The phenotypic variance ( $\left.\sigma^{2} p\right)$ of all traits was higher than the genotypic variance $\left(\sigma^{2} \mathrm{~g}\right)$; similarly, the phenotypic coefficient of variation (PCV) was also higher than the genotypic coefficient of variation (GCV).

The phenotypic coefficient of variability was slightly higher than the corresponding genotypic coefficient of variability for all the traits. Thus, traits with a high phenotypic coefficient of variation indicating that all the characters studied had interacted with the environment. Genetic advance along with a heritability estimate provides a reliable estimate of the amount of genetic advance to be expected through phenotypic selection. High heritability estimates were obtained for bulb yield per hectare (91.39\%), biological yield per plant (91.09\%), number of leaves per plant (89.94\%), clove length (89.10\%), clove diameter (88.61\%), leaves width (85.18\%), clove weight (69.32\%) and leaves length (65.91\%). These characters may respond effectively for selection. Moderate heritability was observed for number of clove per bulb (56.36\%), neck diameter (55.56\%), plant height (52.69\%), bulb length (52.63\%), days to emergence (45.11\%), bulb 
diameter (44.44\%), bulb weight (44.04\%), days to maturity (41.30\%) and bulb yield per plot (40.01\%), but low heritability was recorded for harvest index (9.89\%). Related with the result were reported by Meena et al., (2020) and Abebech et al., (2021).

However, the estimates of heritability alone are not sufficient for predicting the effect of selection. Genetic gain (genetic advance expressed as percent of population mean) ranged from $1.70-63.11 \%$ (Table 4). However, high genetic advance as a percent of mean was recorded for characters clove diameter (63.11\%), neck diameter (60.00\%), bulb yield per hectare (56.90\%), biological yield per plant(49.27\%), leaves length(47.31\%), leaves width (44.09\%), clove length (39.23\%), number of cloves per bulb (35.41\%), bulb yield per plot $(31.19 \%)$, bulb weight $(31.11 \%)$, clove weight (23.06\%) and number of leaves per plant (22.29\%). The findings of the present study are in confirmed with that of Abebech et al., (2021) and Meena et al., (2020).

The correlation between yield per plot and these traits suggested that improvement of these traits could improve the physiological capacity of the crop to mobilize and translocate photosynthetic to the organs of economic value (the bulb), which in turn might have increased the bulb yield as observed in the study. In this study harvest index had a negative association with all traits insignificantly except with plant height and leaves width which exhibited positive and significant correlations. Related with the results have been reported by Abebech et al., (2021) and Valter et al., (2019). From the correlation and path analysis of this experiment biological yield per plant and bulb weight could be considered as main components for selection for bulb yield in a garlic breeding (Rakesh et al., 2018).

These results are in line with Bahadur and Sangeeta, (2016) the character plant height, number of leaves per plant and length of cloves had positive direct effect on bulb yield per plot. The residual effect in path analysis determines how best the component (independent) variables account for the variability of the dependent variable, which is bulb yield. The first four components together accounted for about $79.67 \%$ of the total variation among the genotypes with respect to all the 18 traits evaluated and displayed the presence of substantial genetic diversity among the genotypes for most of the characters below consideration. Whereas, Cluster I and II consisted of two released varieties (HL and Chefe), respectively. This indicates that the crossing between superior genetic divergences of above diverse clusters might provide desirable recombinants for developing high bulb yielding garlic genotypes. Cluster II had mean values greater than overall mean values of genotypes for plant height, leaves length, leaves width, number of leaves per plant, harvest index, respectively, but for the remaining traits cluster II had mean values lower than overall mean values of genotypes.

\section{Conclusion}

Generally, the present study revealed the existence of significant genetic variability among the tested genotypes for different traits helpful for direct and indirect selection. Path coefficient analysis of genotypic revealed that biological yield per plant and leaves width contributes the high and low positive direct effect on bulb yield per plot, respectively. And other characters exerted positive direct effect on bulb yield via number of leaves per plant, bulb length, clove length and clove weight.

These positive direct effects indicate that other characters kept constant, increasing one of these characters was increased bulb yield, which implies that these characters are the major contributor for yield improvement under this study. On the other hand, characters exerted their negative indirect effect via plant height, neck diameter, bulb diameter, bulb weight and number of cloves per bulb. In this study, characters that are significant and positive correlated with bulb yield and had positive direct effect be under consideration. The principal component analysis showed the first four principal components having eigenvalues greater than one accounted for $79.67 \%$ of the total variation of the 36 genotypes evaluated for 18 traits. The genotypes were grouped into three distinct clusters of which Cluster II, I and III consisted of 19(52.78\%), 12(33.33\%) and 5(13.89\%) genotypes, respectively. Cluster I and II constructed by two released varieties (G-HL and Chefe) and Cluster III with 5 genotypes, respectively.

Cluster I was distinguished by having mean values, highest mean values for all traits except for days to emergence and days to maturity and Cluster III characterized as consisting of genotypes with highest mean values for days to emergence (8.40) and days to maturity(110.53). The result suggested the presence of a considerable number of distant garlic genotypes to others that could be used in a crossing program to combine the desirable traits of the genotypes. Finally, the presence of variability among the genotypes, heritability and relationships in the established traits of the genotypes confirmed the option to increase garlic productivity in the target area. Hence, Selection and hybridization on those genotypes based on the trait with high GCV, heritability, genetic advance, and positive correlation coefficient and direct effect on bulb yield can be recommended for further yield improvement of garlic at respective locations.

Availability of data and material. All data sets supporting the conclusions of this article are available in the Electronic supplementary material and from the corresponding author Bayisa Kabe (bayisakabe1868@gmail.com). The achievement of plant breeding material used in this study obeys with institutional, national and international guidelines.

\section{Declarations}

\section{CONFLICT OF INTERESTS}

The authors have not declared any conflict of interests.

\section{ACKNOWLEDGEMENT}

The authors gratefully acknowledgement Ministry of Science and Higher Education (MOSHE) for funding this article work and Haramaya University for providing all the necessary facilities required for the article. We extend our gratitude also to Bishoftu Agricultural Research Center for providing planting materials for Standard Check of garlic varieties and agricultural research farm assistants. 


\section{References}

Abdlkader-Halmy EMS, Abdal-Aziz SA, Abdel-Razzak HS (2011) M.A. Wahab.allah and Al.garban. Evaluation of some agronomic traits and genetic relationships among developed garlic clones by RAPD markers and protein analysis. American-Eurasian

Abebech T, Mijena DF, Zeleke H and G., Tabor (2021) Genetic Variability and Character Association among Bulb Yield and Yield Related Traits in Garlic (Allium sativum L.). Afr Crop Sci J 29(2):293-308

Ahmed MN and J (2018) Variability, Character Association and Path Analysis of Yield and Yield Contributing Traits in Garlic (Allium sativum L.). The faculty of Agriculture, Sher-e-Bangla Agricultural University, Dhaka

Alam MS, Rahim MA, Simon PW (2010) Performance evaluation of garlic germplasm under dry land condition. Journal of Agroforestry and Environment 3:43-45

Alemayehu D, Hirpa L, Negash G (2014) Genetic variability, yield and yield associations of lentil (Lens culinaris Medic.) genotypes grown at Gitilo Najo, Western Ethiopia. Science, Technology and Arts Research Journal 3(4):10-18

Awel D, Getachew T, Sentayew A (2011) Genetic variability and Association of Bulb Yield and Related Traits in Shallot (Allium cepa Var.Aggregatum Don. In Ethiopia Int J Agric Res 6(7):517-536

Bahadur S, Sangeeta S (2016) Morphological and Molecular characterization of garlic (Allium sativum L.). Bihar Agricultural College, Sabour, Bhagalpur Bihar Agricultural University, Sabour Bhagalpur-813 210 (Bihar) India.

Baranwal DK, Mishra VK, Vishwakarma MK, Yadav PS, Arun B (2012) Studies on genetic variability, correlation and path analysis for yield and yield contributing traits in

Benke AP, Khar A, Mahajan V, Gupta A, Singh M (2020a) Study on dispersion of genetic variation among Indian garlic ecotypes using agro morphological traits. Ind J. Genet., 80 (1) (2020), pp. 94-102

Chanchan M, Hore JK, Ghanti S (2014) Response of garlic to foliar application of some micronutrients, J., Crop Weed, 9:138-41

Chatoo MA, Rashid R, Ali A, Bhat FN (2018) Variability, Heritability and Genetic Advance in Garlic (Allium sativum L.). Int J Pure App Biosci 6(2):793-796

Divya D, Sharma A, Chauhan and Madhvi (2021) Genetic variability, heritability and genetic advance in garlic genotypes. Journal of Pharmacognosy and Phytochemistry 10(2):1346-1348

Edwards S, Demissew S, Heberg I (1997) Flora of Ethiopia and Eritrea, vol 6. National Herbarium, Addis Ababa University

Falconer DS (1981) Introduction to Quantitative Genetics, 2nd edn. Longman Inc., New York

FAO (Food and Agriculture Organization of the United Nations) (2012) Area and production of crops by countries. WWW.faostat.fao.org. Accessed in august 2015

FAOSTAT (2018) http://www.fao.org/faostat/en/\#data/QC

Getachew T, Eshetu D, Tebikew D (2009) Guidelines for shallot and garlic production. Debre-Zeit Agricultural Research Center, Debre-Zeit, Ethiopia, (Amharic), pp: 51

Golparvar AR, Ghasemi-Pirbalouti A, Madani H (2006) Genetic control of some physiological attributes in wheat under drought stress conditions. Pak J Biol Sci 9(8):1442-1446

Gupta Arun K, Samnotra RK and Kumar Sanjeev (2007) Variability studies for some important horticultural traits in garlic (Allium sativum L.). Haryana Journal of Horticultural Sciences 36:301-302

Haydar N, Sharker MB, Ahmed MM, Hannan. MA, Razvy M, Hossain A, Hoque, Karim R (2007) Genetic Variability and Interrelationship in Onion (Allium cepa L.). East Journal of Scientific Research, 2 (3-4): 132-134. Bangladesh

Johnson HW, Robinson HF, Comstock RF (1955) Genotypic and Phenotypic correlation in soybean and their implication in selection. Agron J 47:477-483

Kassahun T (2006) Variability and association among bulb yield and related traits in garlic (Allium sativum L.). M.Sc. Thesis, School of Graduate Studies of Alemaya University

Khandagale K, Krishna R, Roylawar P, Ade AB, Benke A, Shinde B, Rai A (2020) Omics approaches in (Allium sativum L.) research. Progress and way ahead Peer J 8:9824 
Khar S, Kumar S, Samnotra RK, Kumar M, Chopra S, Kumar M, Gupta S (2015) Variability and correlation studies in garlic (Allium sativum L.). Indian Journal of Plant Genetic Resources 28:29-236

Kumar K, Ram CN, Yadav GC, Gautum DP, Kumar P, Kumar R (2017) Studies on variability, heritability and genetic advance analysis for yield and yield attributes of garlic (Allium sativum L. International Journal of Current Research in Bioscience and Plant Biology 4:123-129

Lawande KE, Khar Mahajan A, Srinivas PS, Sankar V, Singh RP (2009) Onion and garlic research in India. J. Hortl. Sci., Vol. 4 (2): $91-119,2009$

Manjunathagowda DCJ, Gopal R, Archana, Asiya KR (2017) Virus Free Seed Production of Garlic (Allium sativum L.): Status and Prospects Int. J Curr Microbiol App Sci 6(6):2446-2456

Maurya B, Kumar ADP, Singh, Singh BB (2015) Association analysis in lentil. Indian Journal of Pulses Research 8(1):20-24

Meena S, Yadav S, Kumar R, Singh, Ruchika Abha and Rupesh Kumar Mandel (2020). Genetic Variability, Heritability and Genetic Advances in the Garlic (Allium sativum L.) Genotypes. Biosc.Biotech.Res.Comm. Vol 13 Number (1), Pp-335-339

Panse R, Jain PK, Gupta A, Singh SD (2013) Morphological variability and character association in diverse collections of garlic germplasm. Afr J Agric Res 8:2861-2869

Pervin M, Hassan MK, Hassan K, Hoque AKMA (2014) Genetic variation of indigenous, improved and exotic Allium sativum L. Germplasm. Advances in Plants and Agricultural Research 1:00011

Ranjitha MC, Vaddoria MA, Jethava AS (2018) Genetic Variability, Heritability and Genetic Advance in Garlic (Allium sativum L.) Germplasm. Int J Pure App Biosci 6(4):401-407

Rakesh Sharma V, Malik S, Kumar M, Sirohi A (2018) Morphological Classification of Genetic Diversity of Garlic (Allium sativum L.) Germplasm for Bulb and Yield Related Traits Using Principal Component Analysis. Int J Curr Micro biol App Sci 7(6):2016-2022

Institute Inc SAS (2008) SAS/STATR9.2 User's Guide. Cary, NC: SAS Institute. Inc, Cary, USA.www.support.sas.com/documentation/cdl/PDF; (accessed October/10/2011)

Sable SV, Deshmukh DT, Ghawade SM, Rawat SS (2020) Genetic Variability and Correlation Studies in Garlic (Allium sativum L.). Int. J. Curr. Micro biol. App. Sci, (2020) 9(5): 358-363

Singh G, Mishra DP, Vimlesh K, Pandey DP, Singh S (2015) Genetic diversity in genotypes of garlic (Allium sativum L.) for growth, yield and its attributing traits. Bioscience, Biotechnology Research and Communication 8:149-152

Singh RK, Dubey BK, Bhonde SR, Gupta RP (2011) Correlation and path coefficient studies in garlic (Allium sativum L.). Journal of Spices and Aromatic Crops 20(2):81-85

Valter C, de Andrade Júnior, Amanda G, Guimarães, Tiago D, Firme A, Aparecida A, Costa V (2019) Resende. Associations between morphological and agronomic characteristics in garlic crop. Horticultura Brasileira, 37: 204-209

Vatsyayan S, Brar PS, Dhal RK (2013) Genetic variability studies in garlic (Allium sativum L.). Annals of Horticulture 6:315-320

Yadav N, Kumar, Singh K, Pal, Naidu AK and Nair Bena (2012) Estimation of genetic variability for yield and its components in garlic (Allium sativum L.). Progressive Agriculture 12:26

Wen Y-B, Wu LXiao-XueLHong-Jiu (2020) Cui-Nan, Meng, Huan-Wen, Cheng and Zhi-Hui. High-frequency direct shoot organogenesis from garlic (Allium sativum L.) inflorescence and clonal fidelity assessment in regenerants. Plant cell, tissue, and organ culture. V.141 no.2 pp. 275-287

Yebirzaf Y, Belete N, Tegibew W, Yohaness G, Abayneh M, Kassahun Y (2017) Genetic Variability, Heritability and Genetic advance of Growth and Yield Components of Garlic (Allium sativum L.) Germplasms. Journal of Biology, Agriculture and Healthcare 7(21):2224-3208

\section{Tables}

Table.1. Garlic accessions used for the study and their site of collection 
Source

\begin{tabular}{|c|c|c|c|c|c|c|c|}
\hline & Accession Name & & & & Accessions Name & & \\
\hline $\mathrm{G}^{*}$ & & District & Zone & $\mathrm{G}^{*}$ & & District & Zone \\
\hline G1 & G-158-3/95 & Nekemte & East Wollega & G19 & G-121-2/94 & Meket & North Wello \\
\hline G2 & G-011/95 & Nekemte & East Wollega & G20 & G-089/04 & Chefe Donsa & East Shewa \\
\hline G3 & G-20-2/94 & Waliso & S/West Shewa & $\mathrm{G} 21$ & G-152/06 & Gimbichu & East Shewa \\
\hline G4 & G-064/04 & Chefe Donsa & East Shewa & G22 & G-36-2/94 & Wenchi & S/West Shewa \\
\hline G5 & G-092-3/95 & Nekemte & East Wollega & G23 & G-110/06 & Chefe Donsa & East Shewa \\
\hline G6 & G-70-2/94 & Menjarna & North Shewa & G24 & G-024/04 & Gimbichu & East Shewa \\
\hline G7 & G-013/04 & Gimbichu & East Shewa & $\mathrm{G} 25$ & G-134/06 & Gimbichu & East Shewa \\
\hline G8 & G-145/06 & Gimbichu & East Shewa & G26 & G-032/02 & Menz Mama & North Shewa \\
\hline G9 & G-20-2/95 & Nekemte & East Wollega & G27 & G-099/04 & Chefe Donsa & East Shewa \\
\hline G10 & G-129/06 & Chefe Donsa & East Shewa & $\mathrm{G} 28$ & G-046/06 & Chefe Donsa & East Shewa \\
\hline G11 & G-052/06 & Chefe Donsa & East Shewa & G29 & G-32-1/94 & Wenchi & S/West Shewa \\
\hline G12 & G-002-3/94 & $\| u$ & S/West Shewa & G30 & G-015/06 & Gimbichu & East Shewa \\
\hline G13 & G-119/06 & Chefe Donsa & East Shewa & G31 & G-019/02 & Merhabete & North Shewa \\
\hline G14 & G-057/06 & Chefe Donsa & East Shewa & G32 & G-069/06 & Gimbichu & East Shewa \\
\hline G15 & G-090/06 & Chefe Donsa & East Shewa & G33 & G-040/06 & Chefe Donsa & East Shewa \\
\hline G16 & G-001/04 & Gimbichu & East Shewa & G34 & G-059/06 & Chefe Donsa & East Shewa \\
\hline G17 & G-103/06 & Gimbichu & East Shewa & G35 & $\mathrm{G}-\mathrm{HL}$ & DZARC** & \\
\hline G18 & G-03-1/02 & Merhabete & North Shewa & G36 & G-Chefe & DZARC** & \\
\hline
\end{tabular}

Source: $\mathrm{G}^{\star}=$ Genotype code number used in the article, DZARC** = Varieties Released by Debre-zeit Agricultural Research Center

Table. 2. Analysis of Variance Table for Triple Lattice Designs (TLD)

\begin{tabular}{lclll} 
Source of Variation & Df (Degree of freedom) & SS & MS & F-value \\
\hline Replication & $\mathrm{r}-1$ & $\mathrm{SSr}$ & $\mathrm{MSr}$ & $\mathrm{MSr} / \mathrm{MSe}$ \\
\hline Treatments (Unadjusted) & $\mathrm{t}-1$ & $\mathrm{SSt}$ & $\mathrm{MSt}$ & $\mathrm{MSg} / \mathrm{MSe}$ \\
\hline Blocks(Adj) & $\mathrm{r}(\mathrm{t}-1)$ & $\mathrm{SSb}$ & $\mathrm{MSBAdj}=\mathrm{Eb}$ & $\mathrm{MSb} / \mathrm{MSe}$ \\
\hline Intra- Block Error & $(\mathrm{t}-1)(\mathrm{rt}-\mathrm{t}-1)$ & $\mathrm{SSe}$ & $\mathrm{MSE}=\mathrm{Ee}$ & \\
\hline Total & $\mathrm{Rt}-1$ & Total SS & &
\end{tabular}

\footnotetext{
$\mathrm{SSr}=$ Sum of squares due to replication $\quad \mathrm{SSt}=$ Sum of squares due to treatments

$\mathrm{SSb}=\mathrm{Sum}$ of squares due to blocks $\quad \mathrm{SSe}=$ Error sum of squares

Ee $=$ Effective error mean square $\quad E b=$ Error for block
}

Table. 3. ANOVA table showing mean squares for genotypes block mean square, error mean square, replication mean square and coefficient of variation for 18 traits tested by using triple lattice design. 


\begin{tabular}{|c|c|c|c|c|c|}
\hline Source & & & & & \\
\hline \multirow[t]{2}{*}{ Traits } & MSR & MSB & MSG & MSE & \multirow[t]{2}{*}{ CV\% } \\
\hline & $(\mathrm{DF}=2)$ & $(D F=5)$ & $(\mathrm{DF}=35)$ & $(\mathrm{DF}=65)$ & \\
\hline Days to emergence & 0.15 & 0.54 & $1.11^{\star *}$ & 0.32 & 7.06 \\
\hline Days to maturity & 4.29 & 2.8 & $38.69 * *$ & 12.44 & 3.32 \\
\hline Plant height(cm) & 70.10 & 18.04 & $46.59^{\star \star}$ & 10.72 & 12.58 \\
\hline Leaves length $(\mathrm{cm})$ & 91.28 & 14.18 & $29.63^{\mathrm{ns}}$ & 10.10 & 19.87 \\
\hline Leaves width(cm) & 1.15 & 0.1 & $0.28^{*}$ & 0.015 & 30.76 \\
\hline Leaves number per plant & 0.86 & 0.96 & $2.73^{\star \star}$ & 0.096 & 11.95 \\
\hline Neck diameter(cm) & 0.15 & 0.45 & 0.116 ** & 0.023 & 15.00 \\
\hline Bulb length $(\mathrm{cm})$ & 0.67 & 0.06 & $0.39 * *$ & 0.09 & 10.00 \\
\hline Bulb diameter(cm) & 0.77 & 0.02 & $0.34 * \star$ & 0.10 & 9.69 \\
\hline Bulb weight(gm) & 139.7 & 20.89 & $87.59 \star \star$ & 26.06 & 25.82 \\
\hline Clove length $(\mathrm{cm})$ & 0.16 & 0.08 & $0.46^{\star \star}$ & 0.018 & 23.68 \\
\hline Clove diameter(cm) & 0.29 & 0.13 & $0.56^{\mathrm{ns}}$ & 0.023 & 24.61 \\
\hline Clove weight(gm) & 0.33 & 0.23 & $0.39^{\text {ns }}$ & 0.05 & 20.00 \\
\hline Number of cloves per bulb & 0.41 & 2.88 & $16.38^{\star \star *}$ & 3.35 & 20.22 \\
\hline Bulb yield per plot(gm) & 908 & 64.96 & $183.7 \star \star$ & 61.22 & 29.21 \\
\hline Biological yield per plant(gm) & 1187 & 88.45 & $217.03^{\star *}$ & 6.85 & 26.67 \\
\hline Bulb yield per hectare $\left(\mathrm{kg} / \mathrm{ha}^{-1}\right)$ & 10093 & 721.83 & $2041.1^{\star \star}$ & 62.13 & 29.26 \\
\hline Harvest index (\%) & 26.83 & 20.9 & $53.99^{\mathrm{ns}}$ & 40.61 & 9.32 \\
\hline
\end{tabular}

Where, $n s=$ Non-significant, ${ }^{*}=$ Significant at $(P<0.05),{ }^{*}=$ highly significant at $(P<0.01), M S R=$ Mean squares of replications, MSB $=$ Means squares of block, $M S G=$ Mean squares of genotypes, $M S E=$ Mean squares of error, $C V=$ Coefficient of variation, $D F=$ Degree of freedom.

Table. 4. Estimates of Phenotypic (PCV) and Genotypic (GCV) coefficients of variation, Phenotypic $\left(\sigma^{2} p\right)$ and Genotypic $\left(\sigma^{2} g\right)$ variances, Heritability $\left(H^{2}\right)$, Genetic advance (GA) and Genetic advance as percent of mean (GAM) for 18 traits in 36 garlic genotypes at BARC, Ethiopia in 2020. 


\begin{tabular}{llllllll} 
Traits & $\boldsymbol{\sigma}^{2} \mathbf{p}$ & $\boldsymbol{\sigma}^{2} \mathbf{g}$ & $\mathbf{P C V}(\%)$ & $\mathbf{G C V}(\%)$ & $\mathbf{H}^{2} \mathbf{b}(\%)$ & GA & GAM (\%) \\
\hline DE & 0.58 & 0.26 & 9.80 & 6.60 & 45.11 & 0.71 & 9.10 \\
\hline DM & 21.19 & 8.75 & 4.22 & 2.70 & 41.30 & 3.92 & 3.60 \\
\hline PH & 22.68 & 11.95 & 13.45 & 9.77 & 52.69 & 5.16 & 14.60 \\
\hline LL & 29.63 & 19.53 & 22.97 & 18.65 & 65.91 & 11.21 & 47.31 \\
\hline LW & 0.10 & 0.09 & 24.33 & 22.82 & 85.18 & 0.57 & 44.09 \\
\hline NLP & 0.97 & 0.88 & 12.04 & 11.41 & 89.94 & 1.83 & 22.29 \\
\hline ND & 0.054 & 0.030 & 29.05 & 21.65 & 55.56 & 0.48 & 60.00 \\
\hline BL & 0.19 & 0.10 & 14.52 & 10.54 & 52.63 & 0.47 & 15.75 \\
\hline BD & 0.18 & 0.08 & 12.86 & 8.57 & 44.44 & 0.39 & 11.77 \\
\hline BW & 46.57 & 20.51 & 34.29 & 22.76 & 44.04 & 6.19 & 31.11 \\
\hline CL & 0.17 & 0.15 & 21.37 & 20.18 & 89.10 & 0.75 & 39.23 \\
\hline CD & 0.20 & 0.18 & 34.57 & 32.54 & 88.61 & 0.82 & 63.11 \\
\hline CW & 0.16 & 0.11 & 16.14 & 13.44 & 69.32 & 0.58 & 23.06 \\
\hline NCPB & 7.70 & 4.34 & 30.49 & 22.89 & 56.36 & 3.22 & 35.41 \\
\hline BYPL & 102.04 & 40.83 & 37.83 & 23.93 & 40.01 & 8.33 & 31.19 \\
\hline BYPT & 76.91 & 70.06 & 26.25 & 25.06 & 91.09 & 16.46 & 49.27 \\
\hline BYPH & 721.78 & 659.66 & 30.22 & 28.89 & 91.39 & 50.58 & 56.90 \\
\hline HI\% & 45.07 & 4.460 & 8.320 & 2.620 & 9.890 & 1.370 & 1.700 \\
\hline & & & & & & &
\end{tabular}

Note, $\mathrm{DE}=$ Days to emergence, $\mathrm{DM}=$ Days to maturity, $\mathrm{PH}=$ Plant height $(\mathrm{cm}), \mathrm{LL}=$ Leaves length $(\mathrm{cm}), \mathrm{LW}=\mathrm{Leaves}$ width $(\mathrm{cm}), \mathrm{NLP}=\mathrm{Number}$ of leaves per plant, ND = Neck diameter (cm), BL = Bulb length $(\mathrm{cm}), \mathrm{BD}=$ Bulb diameter $(\mathrm{cm}), \mathrm{BW}=$ Bulb weight $(\mathrm{g}), \mathrm{CL}=\mathrm{Clove}$ length $(\mathrm{cm}), \mathrm{CD}=\mathrm{Clove}$ diameter $(\mathrm{cm}), \mathrm{CW}=$ Clove weight(g), NCPB = Number of clove per bulb, BYPL = Bulb yield per plot, BYPT = Biological yield per plant, BYPH = Bulb yield per hectare and $\mathrm{HI}=$ Harvest index (\%).

Table 5. Estimates of genotypic (above diagonal) and phenotypic (below diagonal) correlation coefficients for eighteen traits of thirty- six garlic genotypes

\begin{tabular}{|c|c|c|c|c|c|c|c|c|c|c|c|c|c|c|c|}
\hline Traits & $\mathrm{DE}$ & DM & $\mathrm{PH}$ & LL & LW & NLP & ND & $\mathrm{HI} \%$ & BL & BD & BW & $\mathrm{CL}$ & $C D$ & cW & NCPB \\
\hline DE & 1.000 & 0.02 & -0.25 & -0.19 & -0.18 & $-0.33^{\star}$ & 0.01 & -0.25 & $-0.36^{\star}$ & $-0.38^{*}$ & $0.33^{*}$ & $-0.34^{\star}$ & -0.14 & -0.20 & -0.04 \\
\hline DM & 0.04 & 1.000 & -0.27 & -0.30 & -0.23 & -0.18 & 0.02 & -0.04 & 0.05 & 0.01 & -0.06 & -0.04 & -0.02 & 0.04 & -0.21 \\
\hline $\mathrm{PH}$ & $-0.27 *$ & -0.20 & 1.000 & 0.48 ** & $0.67 \star \star$ & $0.80 * *$ & $0.45^{\star \star}$ & 0.31 & $0.65^{\star \star}$ & 0.60 ** & $0.67^{\star \star}$ & $0.53^{\star \star}$ & 0.27 & $0.47^{* *}$ & $0.38^{\star}$ \\
\hline LL & -0.1 & $-0.286^{\star}$ & $0.34 *$ & 1.000 & $0.58^{\star \star *}$ & 0.51 ** & 0.20 & 0.15 & $0.38^{*}$ & 0.31 & $0.33^{*}$ & 0.32 & 0.24 & $0.41^{*}$ & 0.12 \\
\hline LW & -0.22 & -0.16 & $0.68^{* *}$ & $0.39 * *$ & 1.000 & $0.66^{\star *}$ & 0.24 & 0.33 & $0.47^{\star \star}$ & $0.45^{\star \star}$ & $0.45^{\star \star}$ & $0.42^{\star}$ & 0.06 & $0.40 *$ & $0.36^{*}$ \\
\hline NLP & $-0.29 *$ & -0.14 & $0.78^{\star *}$ & $0.45^{\star \star}$ & $0.64^{\star \star}$ & 1.000 & $0.52^{\star \star}$ & 0.21 & $0.59 * \star$ & $0.54^{\star \star}$ & $0.55^{\star \star}$ & $0.52^{\star \star}$ & $0.35^{\star}$ & $0.39 *$ & $0.46^{\star *}$ \\
\hline ND & -0.02 & 0.03 & 0.40 ** & 0.10 & 0.30 * & $0.45^{\star \star}$ & 1.000 & -0.05 & $0.36 *$ & $0.41 *$ & $0.37 *$ & $0.39 *$ & 0.08 & 0.28 & 0.21 \\
\hline $\mathrm{HI} \%$ & -0.27 & -0.01 & $0.40 * *$ & 0.06 & $0.35^{\star \star}$ & 0.27 * & -0.01 & 1.000 & 0.27 & 0.27 & 0.30 & $0.14^{*}$ & -0.22 & 0.08 & 0.29 \\
\hline BL & $-0.40 * \star$ & 0.06 & $0.65^{\star *}$ & 0.25 & $0.45^{\star \star}$ & $0.56^{* *}$ & 0.30 * & $0.31 *$ & 1.000 & 0.92 ** & $0.89 * *$ & 0.84 ** & $0.36^{*}$ & $0.76^{* *}$ & $0.33^{\star}$ \\
\hline BD & $-0.40 * \star$ & 0.03 & $0.59 * *$ & 0.22 & $0.44^{\star *}$ & $0.52^{\star \star}$ & $0.33^{*}$ & $0.27 *$ & $0.92^{\star \star}$ & 1.000 & $0.82^{\star *}$ & $0.77 * *$ & $0.32^{*}$ & $0.73^{\star *}$ & $0.33^{\star}$ \\
\hline BW & $-0.35^{\star}$ & -0.02 & $0.67^{\star *}$ & 0.19 & $0.47^{\star \star}$ & 0.50 ** & $0.31 *$ & $0.34^{*}$ & $0.89 * \star$ & $0.83^{\star *}$ & 1.000 & $0.84 \star *$ & $0.36^{*}$ & $0.66^{* *}$ & 0.31 \\
\hline CL & $-0.31 *$ & -0.02 & 0.54 ** & 0.23 & $0.42^{\star \star}$ & $0.49 * \star$ & $0.29 *$ & 0.21 & $0.83^{\star \star}$ & $0.79 * \star$ & $0.86^{\star \star}$ & 1.000 & $0.44^{* *}$ & $0.76^{\star *}$ & 0.19 \\
\hline$C D$ & -0.04 & 0.01 & 0.24 & 0.23 & 0.02 & $0.33^{\star}$ & -0.05 & -0.20 & $0.34^{*}$ & $0.35^{\star \star}$ & $0.35^{\star}$ & $0.48^{\star *}$ & 1.000 & $0.49 * *$ & 0.10 \\
\hline CW & -0.24 & 0.04 & $0.52^{\star *}$ & $0.29 *$ & $0.44^{\star \star}$ & $0.42^{\star *}$ & 0.25 & 0.14 & $0.72^{\star \star}$ & $0.71^{\star *}$ & $0.65^{\star \star}$ & $0.75^{\star \star}$ & $0.49 * *$ & 1.000 & 0.09 \\
\hline NCPB & -0.04 & -0.19 & $0.42^{\star \star}$ & 0.10 & $0.36^{\star \star}$ & $0.44^{\star *}$ & 0.19 & $0.28 *$ & 0.31 * & 0.30 * & 0.30 * & 0.22 & 0.15 & 0.20 & 1.000 \\
\hline BYPL & $-0.33^{*}$ & 0.05 & $0.65^{\star \star}$ & 0.10 & $0.61^{\star \star}$ & $0.58^{\star *}$ & $0.44^{\star \star}$ & $0.35^{\star}$ & $0.84^{\star \star}$ & $0.83^{\star *}$ & $0.91^{\star \star *}$ & $0.80^{\star \star *}$ & 0.20 & $0.65^{\star \star *}$ & $0.35^{\star \star}$ \\
\hline BYPT & -0.26 & 0.01 & $0.59 * *$ & 0.20 & $0.51^{\star *}$ & $0.54^{\star \star}$ & $0.45^{\star \star}$ & 0.17 & $0.80^{* \star}$ & 0.81 ** & $0.85^{\star \star}$ & $0.76^{\star \star *}$ & 0.30 * & $0.62^{\star *}$ & $0.37^{\star *}$ \\
\hline BYPH & 0.06 & -0.19 & -0.09 & $0.36 * \star$ & -0.13 & 0.09 & -0.24 & -0.10 & -0.25 & $-0.26^{\star}$ & $-0.28^{*}$ & -0.15 & $0.30 *$ & -0.13 & 0.17 \\
\hline
\end{tabular}


Note, ${ }^{*}$ and $* \star$, Significant, highly significant at $\mathrm{P}<0.05$ and $\mathrm{P}<0.01$, respectively. $\mathrm{DE}=$ Days to emergence, $\mathrm{DM}=\mathrm{Days}$ to $\mathrm{maturity}, \mathrm{PH}=\mathrm{Plant}$ height$(\mathrm{cm}), \mathrm{LL}=$ Leaves length $(\mathrm{cm}), \mathrm{LW}=$ Leaves width(cm), NLP = Number of leaves per plant, ND = Neck diameter(cm), BL = Bulb length(cm), BD = Bulb diameter(cm), BW = Bulb weight(g), CL = Clove length $(\mathrm{cm}), \mathrm{CD}=$ Clove diameter $(\mathrm{cm}), \mathrm{CW}=$ Clove weight $(\mathrm{g}), \mathrm{NCPB}=$ Number of clove per bulb, BYPL = Bulb yield per plot, $\mathrm{BYPT}=$ Biological yield per plant, BYPH = Bulb yield per hectare, $\mathrm{HI}=$ Harvest index (\%).

Table 6. Estimates of direct (bold and underlined diagonal) and indirect effect (off diagonal) of different traits on bulb yield at phenotypic level in thirty six garlic genotypes evaluated at BARC in 2020

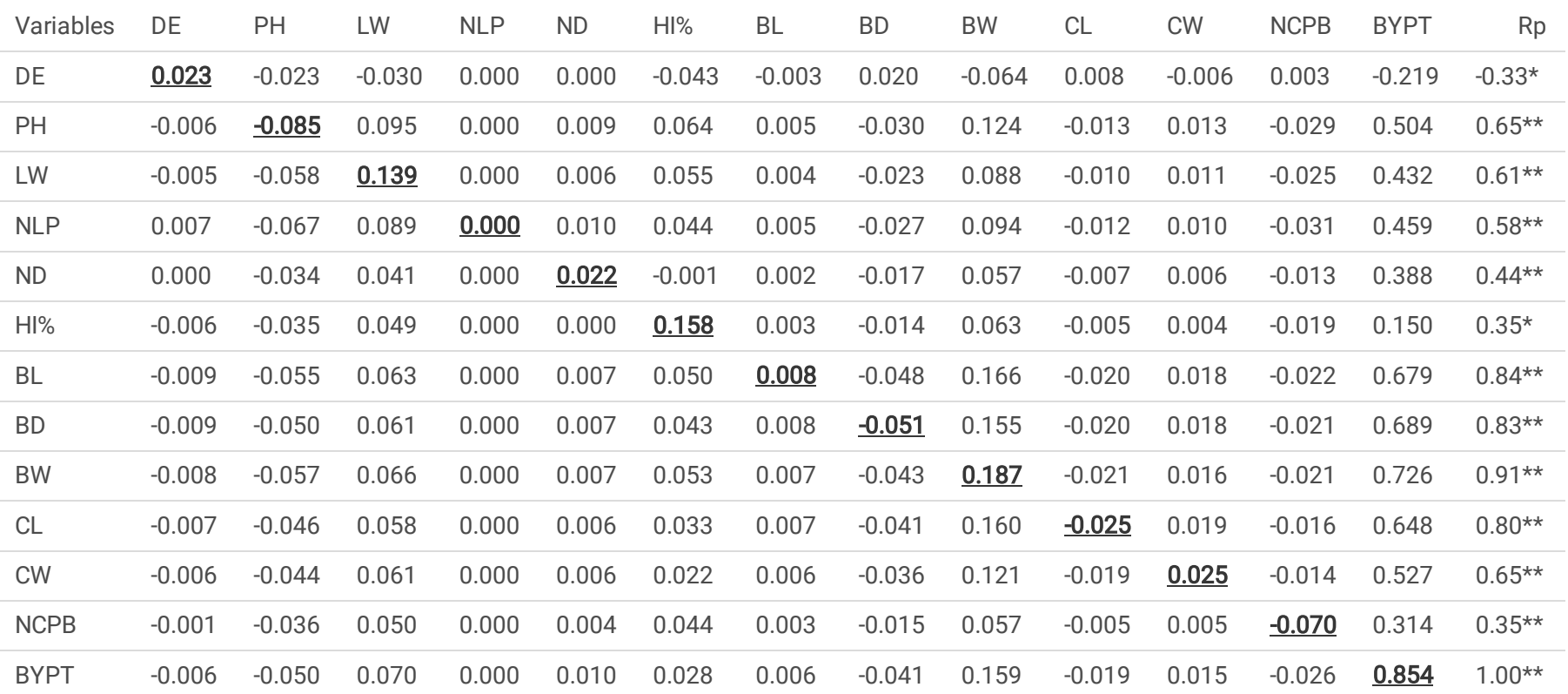

Residual $=\underline{\mathbf{0 . 0 1 7 2}}$ *and** , Significant and highly significant at $\mathrm{P}<0.05$ and $\mathrm{P}<0.01$, respectively and $r \mathrm{p}=$ phenotypic correlation.

$\mathrm{DE}=$ Days to emergence, $\mathrm{PH}=$ Plant height, $\mathrm{LW}=$ Leaves width, NLPP = Leaves number per plant, ND = Neck diameter, BL = Bulb length, BD = Bulb diameter, $\mathrm{BW}=$ Bulb weight, $\mathrm{CL}=$ Clove length, $\mathrm{CW}=$ Clove weight, $\mathrm{NCPB}=$ Number of clove per bulb, BYPT= Biological yield per plant, $\mathrm{HI}(\%)=\mathrm{Harvest}$ index

Table 7. Estimates of direct (bold and underlined diagonal) and indirect effect (off diagonal) of different traits on bulb yield at genotypic level in thirty six garlic genotypes evaluated at BARC in 2020

\begin{tabular}{|c|c|c|c|c|c|c|c|c|c|c|c|c|}
\hline Variables & $\mathrm{PH}$ & LW & NLP & ND & $\mathrm{BL}$ & $\mathrm{BD}$ & BW & $\mathrm{CL}$ & $\mathrm{CW}$ & NCPB & BYPT & $\mathrm{Rg}$ \\
\hline $\mathrm{PH}$ & -0.077 & 0.085 & 0.001 & -0.001 & 0.054 & -0.007 & -0.012 & 0.008 & 0.008 & -0.051 & 0.65 & $0.66^{\star *}$ \\
\hline LW & -0.052 & $\underline{0.130}$ & 0.001 & 0.000 & 0.039 & -0.005 & -0.008 & 0.007 & 0.007 & -0.048 & 0.534 & $61^{\star *}$ \\
\hline NLP & -0.062 & 0.084 & $\underline{0.001}$ & -0.001 & 0.049 & -0.006 & -0.01 & 0.008 & 0.007 & -0.062 & 0.659 & $0.67^{\star *}$ \\
\hline ND & -0.035 & 0.031 & 0.000 & -0.002 & 0.03 & -0.005 & -0.006 & 0.006 & 0.005 & -0.028 & 0.561 & $.56^{\star \star}$ \\
\hline $\mathrm{BL}$ & -0.05 & 0.06 & 0.001 & 0.001 & $\underline{0.083}$ & -0.011 & -0.016 & 0.013 & 0.013 & -0.045 & 0.823 & $0.87^{* *}$ \\
\hline $\mathrm{BD}$ & -0.046 & 0.057 & 0.000 & 0.001 & 0.077 & -0.012 & -0.015 & 0.012 & 0.013 & -0.044 & 0.818 & $0.83^{\star *}$ \\
\hline BW & -0.052 & 0.057 & 0.000 & 0.001 & 0.074 & -0.01 & -0.018 & 0.013 & 0.012 & -0.041 & 0.83 & $0.86^{\star *}$ \\
\hline $\mathrm{CL}$ & -0.04 & 0.053 & 0.000 & 0.001 & 0.07 & -0.009 & -0.015 & $\underline{0.016}$ & 0.013 & -0.025 & 0.727 & $0.79 \star \star$ \\
\hline CW & -0.036 & 0.051 & 0.000 & 0.000 & 0.063 & -0.009 & -0.012 & 0.012 & $\underline{0.018}$ & -0.012 & 0.646 & $0.72^{* *}$ \\
\hline NCPB & -0.029 & 0.046 & 0.000 & 0.000 & 0.028 & -0.004 & -0.005 & 0.003 & 0.002 & $\underline{-0.135}$ & 0.465 & $0.37^{\star *}$ \\
\hline BYPT & -0.05 & 0.068 & 0.001 & -0.001 & 0.069 & -0.01 & -0.015 & 0.011 & 0.011 & -0.063 & 0.998 & 1.00 ** \\
\hline
\end{tabular}

Residual $=\underline{\mathbf{0 . 0 1 8 4}}$, and ${ }^{* *}$, Significant and highly significant at $\mathrm{P}<0.05$ and $\mathrm{P}<0.01$, respectively and $\mathrm{rg}=$ genotypic correlation.

$\mathrm{PH}=$ Plant height, $\mathrm{LW}=$ Leaves width, NLP = Leaves number per plant, ND = Neck diameter, BYPT = Biological yield per plant, BL= Bulb length, BB = Bulb diameter, $\mathrm{BW}=$ Bulb weight, $\mathrm{CL}=$ Clove length, $\mathrm{CW}=$ Clove weight, $\mathrm{NCPB}=$ Number of clove per bulb.

Table 8. Eigenvectors and eigenvalues of the first four principal components of 36 garlic genotypes evaluated for eighteen traits 
Eigenvectors

\begin{tabular}{lllll}
\hline Traits & PC1 & PC2 & PC3 & PC4 \\
\hline Days to emergence & -0.14 & 0.22 & 0.13 & 0.58 \\
\hline Days to maturity & 0.01 & -0.02 & 0.67 & -0.46 \\
\hline Plant height(cm) & 0.27 & 0.23 & -0.08 & 0.02 \\
\hline Leaves length(cm) & 0.20 & 0.34 & 0.03 & 0.14 \\
\hline Leaves width(cm) & 0.25 & 0.24 & -0.11 & 0.16 \\
\hline Leaves a number per plant & 0.23 & 0.39 & 0.002 & -0.18 \\
\hline Neck diameter(cm) & 0.14 & 0.47 & 0.25 & -0.13 \\
\hline Bulb length(cm) & 0.29 & -0.19 & -0.07 & 0.011 \\
\hline Bulb diameter(cm) & 0.29 & -0.16 & -0.11 & 0.05 \\
\hline Bulb weight(g) & 0.29 & -0.20 & -0.04 & 0.05 \\
\hline Clove length(cm) & 0.28 & -0.22 & 0.10 & 0.11 \\
\hline Clove diameter(cm) & 0.20 & -0.28 & 0.15 & 0.35 \\
\hline Clove weight(g) & 0.19 & -0.02 & 0.43 & 0.17 \\
\hline Number of cloves per bulb & 0.16 & 0.24 & -0.42 & -0.21 \\
\hline Bulb yield per plot & 0.30 & -0.06 & 0.02 & 0.002 \\
\hline Biological yield per plant & 0.29 & 0.008 & 0.077 & 0.025 \\
\hline Bulb yield per hectare & 0.30 & -0.06 & 0.021 & 0.003 \\
\hline Harvest index (\%) & 0.17 & -0.26 & -0.17 & -0.38 \\
\hline Eigenvalue & 10.12 & 1.93 & 1.28 & 1.01 \\
\hline Variability (\%) & 56.25 & 10.70 & 7.14 & 5.59 \\
\hline Cumulative \% & 56.25 & 66.95 & 74.08 & 79.67
\end{tabular}

Table 9. Distribution of 36 Garlic genotypes into three different clusters based on 18 quantitative traits evaluated at BARC in $2019 / 20$

\begin{tabular}{lll} 
Cluster & Number Of Genotype & Genotype $\left(\mathrm{G}^{*}\right)$ \\
& & $\mathrm{G} 1, \mathrm{G} 5, \mathrm{G} 6, \mathrm{G} 20, \mathrm{G} 22, \mathrm{G} 23$, \\
\hline Cluster I & $12(33.33 \%)$ & $\mathrm{G} 25, \mathrm{G} 26, \mathrm{G} 29, \mathrm{G} 33, \mathrm{G} 34$, \\
& & $\mathrm{G} 35(\mathrm{HL})$ \\
\hline Cluster II & $19(52.78 \%)$ & $\mathrm{G} 2, \mathrm{G} 3, \mathrm{G} 4, \mathrm{G} 7, \mathrm{G} 8, \mathrm{G}, \mathrm{G} 11, \mathrm{G} 12$, \\
\hline & & $\mathrm{G} 14, \mathrm{G} 15, \mathrm{G} 17, \mathrm{G} 21, \mathrm{G} 24, \mathrm{G} 27$, \\
\hline & & $\mathrm{G} 28, \mathrm{G} 30, \mathrm{G} 31, \mathrm{G} 32, \mathrm{G} 36($ Chefe $)$ \\
\hline Cluster III & $5(13.89 \%)$ & $\mathrm{G} 10, \mathrm{G} 13, \mathrm{G} 16, \mathrm{G} 18, \mathrm{G} 19$
\end{tabular}

G* Genotypes are numbered as shown in Table 1.

Table. 10. Mean value for three clusters based on eighteen quantitative traits evaluated at BARC in 2020 


\begin{tabular}{lllll} 
& \multicolumn{3}{c}{ Cluster } & Overall \\
\hline Trait & Cl & CII & CIII & Mean \\
\hline DE & 7.58 & 7.77 & 8.40 & 7.92 \\
\hline DM & 109.03 & 108.86 & 110.53 & 109.47 \\
\hline PH & 38.50 & 35.03 & 29.43 & 34.32 \\
\hline LL & 14.55 & 13.67 & 11.77 & 13.33 \\
\hline LW & 1.50 & 1.27 & 0.92 & 1.23 \\
\hline NLP & 8.72 & 8.22 & 7.08 & 8.00 \\
\hline ND & 1.13 & 0.73 & 0.33 & 0.73 \\
\hline BL & 3.42 & 2.94 & 2.54 & 2.97 \\
\hline BD & 3.63 & 3.17 & 2.80 & 3.20 \\
\hline BW & 25.80 & 17.82 & 11.65 & 18.42 \\
\hline CL & 2.32 & 1.78 & 1.37 & 1.82 \\
\hline CD & 1.43 & 1.26 & 1.17 & 1.29 \\
\hline CW & 2.76 & 2.38 & 2.29 & 2.48 \\
\hline NCPB & 10.34 & 8.57 & 8.08 & 8.99 \\
\hline BYPL & 35.56 & 23.98 & 15.57 & 25.04 \\
\hline BYPT & 43.33 & 30.61 & 21.12 & 31.69 \\
\hline BYPH & 118.53 & 79.92 & 51.90 & 83.45 \\
\hline HI (\%) & 82.3 & 80.8 & 77.1 & 80.0 \\
\hline
\end{tabular}

Note, $\mathrm{DE}=$ Days to emergence, $\mathrm{DM}=$ Days to maturity, $\mathrm{PH}=$ Plant height $(\mathrm{cm}), \mathrm{LL}=$ Leaves length $(\mathrm{cm}), \mathrm{LW}=\mathrm{Leaves}$ width $(\mathrm{cm}), \mathrm{NLP}=\mathrm{Number}$ of leaves per plant, $\mathrm{ND}=\operatorname{Neck}$ diameter $(\mathrm{cm}), \mathrm{BL}=$ Bulb length $(\mathrm{cm}), \mathrm{BD}=$ Bulb diameter $(\mathrm{cm}), \mathrm{BW}=$ Bulb weight $(\mathrm{cm}), \mathrm{CL}=\mathrm{Clove}$ Length $(\mathrm{cm}), \mathrm{CD}=\mathrm{Clove}$ diameter $(\mathrm{cm}), \mathrm{CW}=$ Clove weight, NCPB = Number of clove per bulb, BYPL $=$ Bulb yield per plot, BYPT $=$ Biological yield per plant, $\mathrm{BYPH}=\mathrm{Bulb}$ yield per hectare, $\mathrm{HI} \%=\mathrm{Harvest}$ index.

\section{Figures}

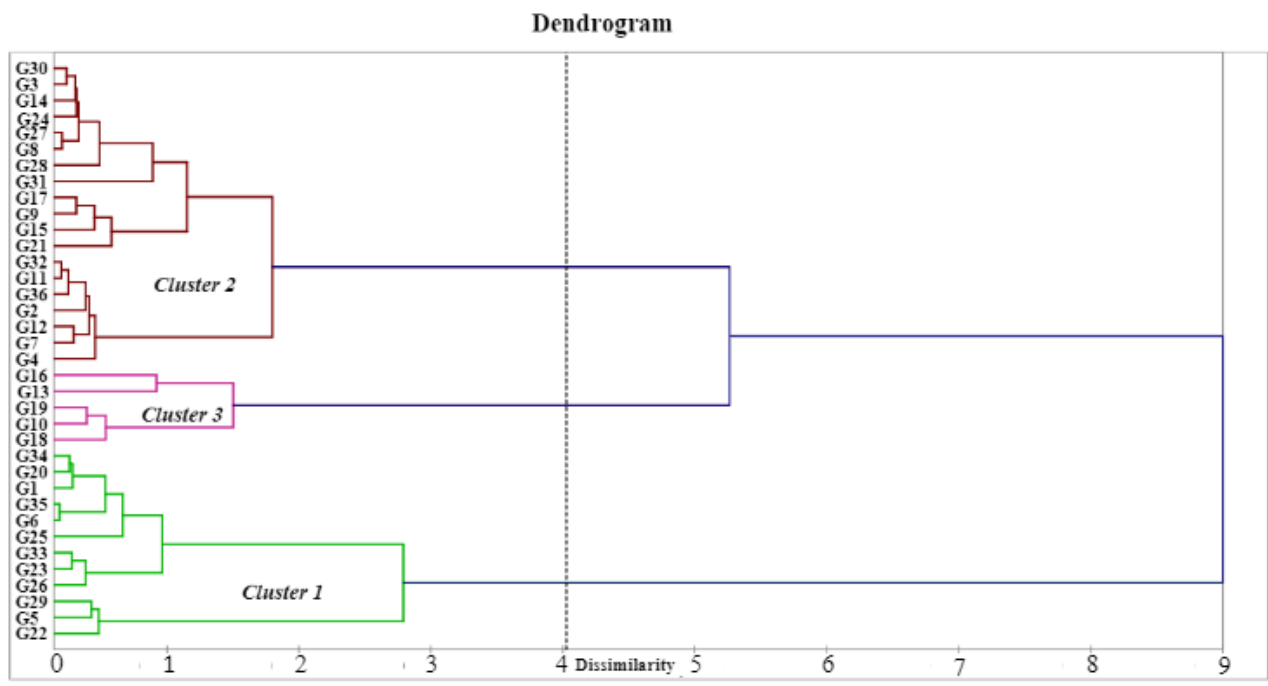

Figure 1

Dendrogram depicting similarity of 36 garlic genotypes (G1-G36 genotypes code as the description given in Table 1) by Unweighted Pair group Method with Arithmetic Means (UPGMA) clustering method for Euclidean distance matrix estimated from 18 phenology, growth traits, bulb yield and yield components.

\section{Supplementary Files}


This is a list of supplementary files associated with this preprint. Click to download.

- Suplementary.docx

Page 16/16 